\title{
Determining Priority Scale in Information Management System in Planning Of Developing Infrastructure in Vocational High School
}

\author{
Sucipto $^{1}$, Tri Joko Rahardjo ${ }^{2}$, Martono ${ }^{2}$, Sugiharto ${ }^{2}$. \\ Civil Enggineering Department ${ }^{1}$ \\ Postgraduate Program ${ }^{2}$ \\ Universitas Negeri Semarang \\ Semarang, Indonesia \\ sucipto@mail.unnes.ac.id
}

\begin{abstract}
Low and insufficient school infrastructure has negative impact on students learning and graduation. Many factors contribute the emerging of infrastructure gap in education. It is caused by the lack of maintenance and old developing, the ineffectiveness of government planning. It needs planning of proposing the developing of school infrastructure using good system, because it is conducted manually in the proposing process. The approach used in the study is qualitative. The study describes the importance of determining priority scale in information management system of planning the infrastructure developing of vocational high school. Data in the study are collected through interview with the headmasters, the Education Chief Board, the chief of Bappeda and budgetting division chief. The document study is conducted by analyzing textbook, note, and archives. The planning of developing school infrastructure must be done systematically by using system. Previously, the planning of developing infrastructure has not supported by available system. The determining criteria is the most important factor because it is used as basic to determine priority scale. Thing must be attended in selecting the criteria to make complete, inexcessive operational, precision and conformity decision. Conceiving criteria of priority scale precisely makes the chief of education board and the decision maker are easy to determine which school gets the first grant to build school infrasturucture and what infrastructure is fulfilled by the government. By using information management system, the planning of developing school infrastructure based on priority scale make the vocational school easy to propose and the other sides feel easy to approve, monitor, and evaluate the planning process and the developing.
\end{abstract}

Keywords-priority scale, information management system, developing infrastructure, vocational high school

\section{INTRODUCTION}

low and insufficient school infrastructure has negative impact on students' learning and graduation. Many factors contribute the gap of infrastructure in education sector. The lack of maintenance and the old developing, the ineffectiveness of the government planning [1]. Education infrastructure is estimated as 10 million classess and grant of 100 million dollar to build school infrastructure over the world to realize Millennium Development Goals [1], since the bad infrastructure of education causes the bad mark of the students' achievement [1]. The implementation of regional autonomy and education decentralization have impact on the quality of education implementation which must be suitable with the standard decided and fulfill the society expectation as well as anticipate the spread of imbalance quality among regions.

Based on the infrastructure, many things are related to the school infrastructure. Each education unit including vocational high school must provide infrastructure to fulfill the education needs based on the growth and development of physical potential, intelectual, social, emotional, and mental intelligence of the students. Standard of infrastructure includes the minimum requirement of area, classroom, education unit principal, teacher room, administration room, library, laboratory, machinery shop, canteen, power and service instalation, sport, praying, recreation, and other rooms needed to support orderly and continuous learning process.

Standard of education infrastructure includes the minimum requirements of utensils, education tools, education media, books, used thing, and other tools needed to support orderly and continuous learning process. Based on the stated principles, everything related to the education stakeholder have to refer to the standard decided. Of the policy, the available fund is limited and is not compared to the condition, problem, and need of the different regency of city government, so that the implementation must attend to the concept of priority scale. In fact, most of the regency or city government have not made list of priority scale of which school must get the grant. It is forgiven because the regency /city government does not have any comprehensive review of (infrastructure) the whole school existed, therefore, the problem will emerge when they must decide which school getting the first grant.

Priority scale is a list containing needs which should be fulfilled by human based on the level and the fulfillment. There are several categories of priority, namely emergency, urgent, high priority, medium priority, low priority, and no priority. The ways to determine the priority scale are including steps which have been done (1) writing the needs, delete the needs which is not so important; (2) conceiving needs arrangement based on the urgency level; (3) making note of the needs of fund existed; (4) selecting the needs giving optimum benefit; (5) fulfilling the entire needs based on the list decided [2]. 
System is a set of elements integrated having same intention to achieve the goal [3]. System is a set of component interrelated and cooperated to achieve a goal. Based on both notion, it can be inferred that a system is a set of element integrated and cooperated to achiave a particular goal [4]. Information system is a set of element interrelated each other forming a unit to integrate data, to process and to save as well as to distribute information [5].

Planning is determining work which is going to be done to achieve the decided goal [6]. Planning is an activity of thinking, studying, counting, and formulating actions going to do in the future, either relating to the operational activity or in establishing, managing, using, organizing, and controlling the infrastructure. Principally, planning is a process of an activity describing previously the things going to do then to achieve the determined goal. In this case, planning is making detail the planning to purchasing, establishing, rehabilitating, distributing, or making equipment and tools based on the necessity.

Referring to the regulation of national education system or Undang-Undang Sistem Pendidikan Nasional No. 20 in 2003 on article 3 concerning about the objective of national education and the explanation of article 15 , it states that vocational school is the high education preparing students to work in certain field. Vocational education is an education preparing students to work in a particular field. The definition contains a statement that each institution holding vocational education has commitment to make the graduation are able to work in a particular field. The development of infrastructure in vocational school still needs attention because the school needs more building for practicing learning.

Efficiency in using cloud computing becomes a principal reason to use technology of cloud computing. The study analyzes and builds cloud computing infrastructure in an education sector case study. Infrastructure developed is a service of Server as a Service aiming to fulfill the needs of students'. The infrastructure is developed based on users requirement gotten by interview. The method of the study is experiment consisting of nine steps. The result of the analysis shows a IaaS prototype developed which has fulfilled the needs to conduct students' experiment with better performance compared to the running system. The performance is shown on the efficiency in setup time, ability and access area. The lack of prototype IaaS lies in the time response and package install [7].

A study conducted in Pakistan analyzed a national information system for education administrator in Pakistan. The study aimed to identify the information system. The result of the study showed that there are many information or library center and information network in education area of Pakistan, consisted of academic library, national and particular. The basic weakness is the infrastructure of library / information center and information network as well as the disintegration of information network. The information lies in the library / information center and information network,

Efficiency. Criteria to determine priority scale is suitable with the analysis of school needs, describing important things related to the needs of developing school. The school, therefore, is more efficient in using time. The data input process is also more practical and directed. but education administrator has problem in browsing the information. Consequently, the available information is not used properly in planning and developing education in Pakistan. The needs to collect information source, service and network in a certain site to build integrated information system which can give holistic description and comprehensive about education effort to plan and alocate realistic resources.[8]

The use of information in a planning management for developing vocational school infrastructure is highly important in order that the entire process of development run well and suitable with the priority. Thus, it needs a priority scale in an information management system for planning the vocational school infrastructure development.

\section{METHOD}

It is a study using qualitative approach in which the study does not use counting [9] or it is termed as scientific study emphasizing the natural character of data resource. It describes the importance of priority scale in information management system of planning the infrastructure of vocational school. The location or the objects of the study are SMK Negeri in Kota Salatiga, namely SMK N 1, SMK N 2 and SMK N 3 Salatiga. Data of the study were collected by interview to the headmasters, the chief of education board, the chief of Bappeda, and the budgetting division chief. The document study was done by book analysis, note, and archives.

\section{RESUlt AND Discussion}

Based on the interview to the headmasters, the education board chiefs, the chief of Bappeda and the budgetting division chief, the determining criteria in determining criteria of conformiting priority scale of a system is important. The planning of developing school infrastructure must be done systematically using system. Previously, the planning of developing infrastructure has not been supported by adequate system. Determining criteria is the most important factor because it is used as a principle to determine priority scale. Several things must be attended in selecting criteria of decision making, namely:

Complete. Identifying criteria must be completed so that it involves the whole important aspects in the issue faced. A criteria set is stated as complete when it can show the goal achievement.

Operational. The operational aspect includes the notion that the set of criteria is valuable for the decision makers, so they are able to notify the implication toward the existed alternatives. Besides, if the objective of decision making has to be used as a means to insist other side, then the set of criteria must be available to use as a means to give explanation or a means of communication.

Inexcessive. It aims to avoid the reestimation, in determining criteria, there should not be any criteria having similar definition.

Conformity. The criteria determined have reflected the conformity of the purpose, needs and future plan. The data sent to the government or to the board, therefore, is clear. It may reduce mistakes in realizing the development.

Hence, before conceiving a system for planning the developing school infrasructure it is conducted the 
determining of priority scale first of what is fast executed the data input. By conceiviing precise criteria of priority scale, it makes the chief of the education board or the other decision makers to decide which school get the grant to develop school infrastructure first, as well as what infrastructure given by the government. By using priority scale base information management system it makes the school easy in proposing and the related sides in approving, monitoring, and evaluating from the planning process to the developing realization.

The results of this study conducted by Muntasar et. al. reveal that the limitations of funds for the construction of road infrastructure from the central government, causing the fulfillment of all road construction needs either the opening of new roads, road improvements, and road rehabilitation. Determining priority scale can be used as a reference in project programming for the next fiscal year. Determining the priority scale of the road development project should look at the various criteria to produce accurate and precise results. The criteria used in determining the priority scale are; road conditions, number and population growth, regional economic potential, cost, and importance level. From the analysis of these criteria, it is found that the variable has high priority and role to influence the result[10].

\section{ACKNOWLEDGMENT}

This research was supported by the Headmaster of SMK 1, SMK 2 and SMK 3 in Salatiga City, Bappeda. We say thanks for our colleagues from Unnes who provided insight and expertise that greatly assisted the research, although they may not agree with all of the interpretations/conclusions of this paper. We would like to thank our dissertation promotion.

\section{REFERENCES}

[1] A. I. Gershberg, "Educational Infrastructure, School Construction,\& Decentralization in Developing Countries: Key Issues for an Understudied Area," International Center for Public Policy, vol. 14, p. $35,2014$.

[2] waluyo, Perpajakan Indonesia Buku I. Jakarta Salemba Empat, 2008.

[3] M. Pearson, Sistem Informasi Manajemen. Salemba: Jakarta, 2008.

[4] J. Satzinger, Burd, System Analisis and Design with the Unified Process. USA: Cengage Learning, 2010.

[5] B. S. D. Oetomo, Perencanaan dan Pembangunan Sistem Informasi. Yogyakarta: Penerbit Andi, 2002.

[6] G. Terry, Dasar-dasar manajemen. Jakarta: PT. Bumi Aksara, 2005.

[7] E. d. Zulfiaji, "Analisis dan Pembangunan Infrastruktur Cloud Computing," Jurnal Cybermatika, vol. 1, p. 4, 2013.

[8] F. S. d. K. Mahmood, "Scanning the information infrastructure of Pakistan: A step towards the development of a national educational information system," vol. 61, 2012.

[9] Lexy J Moleong, Metodologi Penelitian Kualitatif,. Bandung: Remaja Rosdakarya, 2002.

[10] E. J. K. Theresia Fitriyani Muntasar, R. J. M. Mandagi, "Penentuan Skala Prioritas Proyek Pembangunan Jalan di Kabupaten Banggai Kepulauan dengan Menggunakan proyek hirarki analitik " MEDIA ENGINEERING, vol. 1, 2011. 